\title{
Effects of a Trans-Galactooligosaccharide on Minerals Content of Common Carp (Cyprinus carpio L.) Tissues
}

\author{
Ewa Ziółkowska ${ }^{1}$ (D) · Joanna Bogucka ${ }^{1} \cdot$ Jan Mazurkiewicz ${ }^{2} \cdot$ Mateusz Rawski $^{2}$ - Szymon Różański ${ }^{3}$. \\ Magdalena Stanek ${ }^{1}$
}

Received: 28 October 2020 / Accepted: 13 January 2021 / Published online: 26 January 2021

(C) The Author(s) 2021

\begin{abstract}
Common carp (Cyprinus carpio L.) is a dominant fish species in aquaculture, and as it is a stomachless species, absorption and digestion of nutrients take place in the intestine. The aim of the study was to evaluate the effects of a prebiotic on the content of selected minerals found in the meat, gills, and skeleton of common carp. The research applied trans-galactooligosaccharide (GOS) prebiotic produced by enzymatic transgalactosylation of milk lactose by whole cells of Bifidobacterium bifidum. The following diets have been applied: control diet without feed additives (C), diet 2 (B1) with $1 \%$ of GOS, and diet 3 (B2) with 2\% of GOS. In the freeze-dried samples, concentrations of the analyzed metals were determined using atomic absorption spectroscopy (AAS). The content of phosphorus was determined using colorimetric method. The analyses confirmed that the highest level of $\mathrm{Mg}$ was detected in the skeleton of fish fed with $1 \% \mathrm{GOS}\left(2.51 \mathrm{~g} \mathrm{~kg}^{-1}\right)$ and was significantly higher compared the control treatment $\left(2.11 \mathrm{~g} \mathrm{~kg}^{-1}\right)(P<0.05)$. Zn content in fish meat fed with $1 \% \mathrm{GOS}\left(35.41 \mathrm{mg} \mathrm{kg}^{-1}\right)$ was significantly higher $(P<0.05)$ than in the control group $\left(24.59 \mathrm{mg} \mathrm{kg}^{-1}\right)$. The tissue that accumulated the greatest amount of $\mathrm{Zn}$ was the gills. GOS had a positive effect on $\mathrm{Fe}$ accumulation in the meat, gills, and skeleton. It has been concluded that supplementation of feed with $2 \%$ GOS significantly influenced the positive correlations between $\mathrm{Mg}$ and $\mathrm{P}$ in the meat and skeleton, $\mathrm{Fe}-\mathrm{Ca}$ correlation in gills, and $\mathrm{Fe}-\mathrm{Zn}$ correlation in the skeleton.
\end{abstract}

Keywords Prebiotic $\cdot$ Carp $\cdot$ Meat $\cdot$ Gills $\cdot$ Skeleton $\cdot$ Minerals

\section{Introduction}

Fish is one of the most valuable food sources of minerals, the concentration of which is influenced by many endogenous and exogenous factors. There are many factors present in the feed that can inhibit the absorption of minerals, e.g., phytates, fibers, and heavy metals [1-3]. Moreover, the degree of mineral absorption is influenced by the physicochemical

Ewa Ziółkowska

ewa.ziolkowska@utp.edu.pl

1 Department of Animal Physiology, Physiotherapy and Nutrition, Faculty of Animal Breeding and Biology, UTP University of Science and Technology, Mazowiecka 28, 85-004 Bydgoszcz, Poland

2 Division of Inland Fisheries and Aquaculture, Faculty of Veterinary Medicine and Animal Science, Poznań University of Life Sciences, Wojska Polskiego 71C, 60-625 Poznań, Poland

3 Laboratory of Feed and Raw Animal Materials, Faculty of Animal Breeding and Biology, UTP University of Science and Technology, Mazowiecka 28, 85-004 Bydgoszcz, Poland properties of water, such as hardness, salinity, and $\mathrm{pH}[3,4]$. Changes in the dietary composition and mineral concentration of rearing water could have an impact on the mineral balance in fish tissues and proper physiological state of animals. One of the most serious health and economic problems in the world of marine and freshwater aquaculture is the fish body deformation $[5,6]$. Initially, deformations of the food-based skeleton were explained by the vitamin $\mathrm{C}$ deficiency in diet, yet currently the main cause of these deformations has been attributed to the deficiency of minerals [6]. A research has confirmed that the presence and proper balance between $\mathrm{Ca}, \mathrm{P}$, $\mathrm{Mg}$ and $\mathrm{Zn}$ are necessary for the correct mineralization of the fish skeleton $[3,6,7]$. Moreover, since excessive $\mathrm{Fe}$ intake inhibits $\mathrm{Zn}$ absorption (antagonistic effect), analyzing $\mathrm{Fe}$ levels should also be considered.

Common carp (Cyprinus carpio L.) has been a dominant fish species in the world aquaculture production [8] and was the first species introduced into Polish aquaculture. The first records on farming date back to the twelfth century, and after the year 1550 , common carp accounted for about $75-80 \%$ of all fish farmed in ponds. Poland and the Czech Republic are 
the largest producers of common carp in the European Union, and the annual production of consumable common carp in Poland ranges between 15 and 23,000 t $[9,10]$. Common carp is an omnivorous species with low nutritional requirements, both in terms of the feed composition and its production technology. In addition, common carp farmed in ponds largely relies on a natural diet which usually consists of the biomass produced by the pond. Carp does not have functional stomach, and digestion takes place in the intestine hence from digestibility food, and assimilation is limited. Due to the fact that the cyprinids do not have acid-secreting stomachs, the mineral absorption from organic compounds (in particular phosphorus) may be reduced $[11,12]$.

In recent years, the influence of various factors on the degree of fish mineralization has been studied such as different starter diets or water temperature [6,13-15]. To our knowledge, there is little data available on the effect of prebiotics on the accumulation of minerals in different tissues of common carp. As confirmed by research prebiotics (e.g., fructooligosaccharides (FOS), transgalactooligosaccharides (t-GOS), inulin, and mannanooligosaccharides (MOS)) have a positive effect on the gut microbiota composition. They inhibit the growth of pathogenic gut microbial flora while stimulating the growth of microorganisms beneficial for the animal host. Beneficial gut bacteria can improve the body's natural defenses, synthesize vitamins, and bind toxins and heavy metals. In aquaculture, prebiotics are increasingly used due to their positive effect on growth stimulation, use of feed, gut microflora, gut morphology, immune system, and disease resistance [8, 16-23]. These bioactive substances play an important role in regulating mineral metabolism, mineral bioavailability, and bone health [23-27]. Moreover, prebiotics affect the production of shortchain fatty acids, lowering the intestinal $\mathrm{pH}$, regulating the factors responsible for the transport of divalent metals, thanks to which they improve the absorption of metals and skeletal health [28-32]. Some authors confirmed, that prebiotics and their products of fermentation by intestinal microflora have an enhancing effect on $\mathrm{Fe}$ and $\mathrm{Zn}$ absorption [23, 24, 33, 34]. Therefore, it definitely seemed valid to analyze the degree of absorption of minerals by carp family member (representatives of the Cyprinidae family) under prebiotic supplementation.

The prebiotic used in this experiment, under the trade name $\mathrm{Bi}^{2}$ tos, is manufactured by Clasado (Biosciences Ltd., Jersey, UK) by enzymatic transgalactosylation of milk lactose by whole cells of Bifidobacterium bifidum 41171. For this reason, $\mathrm{Bi}^{2}$ tos specifically promotes growth of Bifidobacterium spp. [35]. Our previous research revealed that the supplementation of feed with $1 \%$ and $2 \% \mathrm{Bi}^{2}$ tos significantly enhanced the development of the intestine, increased the height and width of the villi, and increased their surface area [36], which may contribute to increased absorption of nutrients from the gut.

The aim of the present study was to analyze the effects of dietary supplementation of a trans-galactooligosaccharide
(GOS) on the content of selected minerals in the meat, gills, and skeleton of common carp and on the correlations between minerals analyzed.

\section{Material and Methods}

Studies on live animals were carried out in strict accordance with the recommendations of the National Ethics Commission (Warsaw, Poland). All members of the research staff were trained in animal care, handling, and euthanasia. Fish health and welfare and the environmental conditions in the experimental tanks were checked twice daily by visual observation of animal behavior and by checking water quality parameters, such as oxygen saturation, temperature, and water flow. After sedation, the animals were decapitated according to the American Veterinary Medical Association Guidelines for the Euthanasia of Animals [37]. According to Polish law and an EU directive (no 2010/63/EU) [38], the experiments conducted in this study did not require approval from the Local Ethical Committee for Experiments on Animals in Poznań.

\section{Experimental Diets}

The experimental diets were calculated as isonitrogenous (35.1\% crude protein) and isoenergetic $\left(18.5 \mathrm{MJ} \mathrm{kg}^{-1}\right)$ with less than $4 \%$ of crude fiber and were formulated according to common carp nutritional requirements [39-41]. Three experimental diets were used: control diet 1 (C) without feed additives, diet 2 with $1 \%$ of GOS (B1), and $\operatorname{diet} 3$ (B2) with $2 \%$ of GOS (Table 1).

The experimental diets were prepared according to the following procedures below:

1. Preparation of components of the diets: individual components weighed out; ground in a percussion mill until very fine (mesh size $1 \mathrm{~mm}$ ).

2. Preparation of the premix: vitamin and mineral components, soybean lecithin, choline chloride, chalk, and prebiotic were added to the carrier (soybean meal); mixed for 5 min in a cubic mixer.

3. Preparation of the diets: all ingredients and the premix mixed in a drum mixer for $5 \mathrm{~min}$.

4. Conditioning the diets: hot water added; mixed in blade mixer for $5 \mathrm{~min}$.

5. Extrusion: Metalchem S-60 single screw warm extruder (Gliwice, Poland), the extrusion conditions were as follows: a $90{ }^{\circ} \mathrm{C}$ cylinder temperature in the zone of increasing pressure, a $100^{\circ} \mathrm{C}$ cylinder temperature in the zone of high pressure, a $110^{\circ} \mathrm{C}$ head temperature, a 52-rpm speed screw, and a 6-mm nozzle diameter.

6. Drying: on mesh under a stream of heated air.

7. Sifting: the dust fraction sifted off in a percussion sifter. 
Table 1 Dietary formulation and proximate composition of feed

\begin{tabular}{|c|c|c|c|}
\hline \multirow[t]{2}{*}{ Ingredient } & \multicolumn{3}{|c|}{ Composition (\%) } \\
\hline & $\mathrm{C}$ & B1 & B2 \\
\hline Fish meal $^{1}$ & 12.3 & 12.3 & 12.3 \\
\hline Blood meal ${ }^{2}$ & 10.0 & 10.0 & 10.0 \\
\hline DDGS $^{3}$ & 11.0 & 11.0 & 11.0 \\
\hline Soybean meal $^{4}$ & 15.0 & 15.0 & 15.0 \\
\hline Rapeseed meal $^{5}$ & 10.0 & 10.0 & 10.0 \\
\hline Wheat meal & 32.8 & 31.8 & 30.8 \\
\hline Fish oil ${ }^{6}$ & 4.6 & 4.6 & 4.6 \\
\hline Soybean lecithin ${ }^{7}$ & 1.0 & 1.0 & 1.0 \\
\hline Vitamin-mineral premix ${ }^{8}$ & 1.5 & 1.5 & 1.5 \\
\hline Vitamin premix ${ }^{9}$ & 0.1 & 0.1 & 0.1 \\
\hline Choline chloride & 0.2 & 0.2 & 0.2 \\
\hline Fodder chalk & 1.5 & 1.5 & 1.5 \\
\hline Prebiotic $^{10}$ & 0.0 & 1.0 & 2.0 \\
\hline \multicolumn{4}{|c|}{ Proximate composition ( $\%$ dry matter) } \\
\hline Crude protein & 35.06 & & \\
\hline Crude lipid & 9.08 & & \\
\hline Crude fiber & 3.93 & & \\
\hline Total phosphorus & 0.83 & & \\
\hline Calcium & 1.36 & & \\
\hline Ash & 7.17 & & \\
\hline Gross energy $\left(\mathrm{MJ} \cdot \mathrm{kg}^{-1}\right)$ & 18.51 & & \\
\hline Essential amino acids & $\mathrm{g} / 100$ & & \\
\hline Arginine & 4.53 & & \\
\hline Histidine & 2.8 & & \\
\hline Lysine & 3.5 & & \\
\hline Tryptophan & 1.04 & & \\
\hline Phenylalanine + tyrosine & 4.96 & & \\
\hline Methionine + cysteine & 1.75 & & \\
\hline Threonine & 3.13 & & \\
\hline Leucine & 6.72 & & \\
\hline Isoleucine & 3.9 & & \\
\hline Valine & 4.97 & & \\
\hline
\end{tabular}

${ }^{1}$ Danish fishmeal, Type F, $72 \%$ total protein, $12 \%$ fat, FF Ska-gen, Denmark

${ }^{2}$ AP 301 P, 92\% total protein, APC (GB) Ltd., Ings Road, Doncaster, UK

${ }^{3}$ Dried distillers grains with solubles, $>45 \%$ total protein, $<6 \%$ ash

${ }^{4}$ Toasted, $46-47 \%$ total protein, $1 \%$ fat

${ }^{5} 33 \%$ total protein, $2 \%$ fat

${ }^{6}$ Agro-fish, Kartoszyno, Poland

${ }^{7}$ BergaPure, deoiled lecithin, 97\% pure lecithin, Berg + SchmidtGmbH \& Co. KG, Hamburg, Germany

${ }^{8}$ Polfamix W, BASF Polska Ltd. Kutno, Poland - $1 \mathrm{~kg}$ contains vitamin A 1000000 IU, vitamin D3 200,000 IU, vitamin E $1.5 \mathrm{~g}$, vitamin K $0.2 \mathrm{~g}$, vitamin B1 $0.05 \mathrm{~g}$, vitamin B2 $0.4 \mathrm{~g}$, vitamin B12 $0.001 \mathrm{~g}$, nicotinic acid $2.5 \mathrm{~g}$, Dcalcium pantothenate $1.0 \mathrm{~g}$, choline chloride $7.5 \mathrm{~g}$, folic acid $0.1 \mathrm{~g}$, methionine $150.0 \mathrm{~g}$, lysine $150.0 \mathrm{~g}, \mathrm{Fe} 2.5 \mathrm{~g}$, Mn 6.5 g, Cu 0.8 g, Co 0.04 g, Zn 4.0 g, J 0.008 g, carrier up to 1000.0 g

${ }^{9}$ Vitazol AD3E, BIOWET Drwalew, Poland - $1 \mathrm{~kg}$ contains vitamin A $50000 \mathrm{IU}$, vitamin D3 5000 IU, vitamin E $30.0 \mathrm{mg}$, vitamin C $100.0 \mathrm{mg}$

${ }^{10}$ Bitos ${ }^{\circledR}$ trans-galactooligosaccharide (GOS), Clasado Ltd.; dry powder containing a mixture (wt: wt) of the following oligosaccharides: $45 \%$ lactose, 9.9\% disaccharides [Gal-( $\beta 1-3)-\mathrm{Glc}$; Gal-( $\beta 1-3)-\mathrm{Gal}$; Gal-( $\beta 1-6)-$ Gal; Gal- $(\alpha 1-6)-\mathrm{Gal}$, $23.1 \%$ trisaccharides [Gal- $(\beta 1-6)-\mathrm{Gal}-(\beta 1-4)-\mathrm{Glc}$; Gal-( $(\beta 1-3)-\mathrm{Gal}-(\beta 1-4)-\mathrm{Glc}]$, $11.55 \%$ tetrasaccharides $[\mathrm{Gal}-(\beta 1-6)-\mathrm{Gal}-(\beta 1-6)-\mathrm{Gal}-(\beta 1-4)-\mathrm{Glc}]$, and $10.45 \%$ pentasaccharides $[\mathrm{Gal}-(\beta 1-$ 6)-Gal-( $\beta 1-6)-\mathrm{Gal}-(\beta 1-6)-\mathrm{Gal}-(\beta 1-4)-\mathrm{Glc}]$ 
8. Oiling: fish oil heated to $50{ }^{\circ} \mathrm{C}$ in quantities of $4.6 \%$ was used to coat extruded diet in a pelletizing drum.

9. Final sifting: the dust fraction sifted off in a percussion sifter.

Prepared feeds have been packed in foil bags and stored minus $18{ }^{\circ} \mathrm{C}$ until use.

\section{Fish Culture}

The 60-day growth trial was carried out in the Experimental Station for Feed Production Technology and Aquaculture in Muchocin (Poland). Three hundred one-year-old common carp (mean body weight $180 \mathrm{~g}$ ) were used. The fish were randomly stocked into 12 concrete ponds $\left(40 \mathrm{~m}^{3}\right)$, at a density of 25 fish per pond according to Horváth et al. [42]. The experiment was carried out in four replications (four ponds per treatment). Each pond was equipped with an automatic band feeder allowing for the continuous supply of feed during $12 \mathrm{~h}$ per day. The calculated daily feed dose for each pond was given every day at 9.00 a.m., its consumption was controlled visually twice a day, and rate was corrected if needed. The daily feed dose was restricted to assure that all feed supplied was consumed. The feeding rate was calculated in consideration of fish biomass in each pond which was corrected every 10 days on the basis of control bulk weighing of all fish; measurements of the current average daily water temperature and feed consumption from previous day were used for the additional correction according to Miyatake's [43] recommendations, which resulted in feeding rate ranging from 1.8 to $3.3 \%$ of fish biomass. A constant flow of water in the experimental system was ensured by an open flow system with a mechanical pre-filtration chamber providing total exchange of water capacity in each pond every $12 \mathrm{~h}$. During the experimental period, control of water physio-chemical parameters was carried out with the use of microcomputer oximeter Elmetron CO-315. Average daily water temperature and $\mathrm{pH}$ were studied which ranged from $17.7^{\circ} \mathrm{C}$ to $22.7^{\circ} \mathrm{C}$ and 7.2 to 7.6, respectively. Dissolved oxygen was kept above $3.5 \mathrm{mg}$ $\mathrm{O} 2 / \mathrm{L}$, and hypoxia conditions were not observed in the experiment (details are described in Ziółkowska et al. [36]).

During the experiment, fish were anesthetized by immersion in $130 \mathrm{mg} / \mathrm{L}$ tricaine methanesulfonate (MS-222, Sigma Aldrich) for weighing at 10-day intervals for feed rate control. Body weight gain (BWG), feed intake (FI), feed conversion ratio (FCR), specific growth rate (SGR), protein efficiency ratio (PER), and percentage weight gain (PWG) were calculated (details are described in Ziółkowska et al. [36]).

\section{Sample Preparation}

At the end of the experiment, four fish per pond were euthanized by immersion in $500 \mathrm{mg} \mathrm{L}^{-1}$ of MS-222 [44] for tissue sampling for metals analysis. The number of individuals subjected to analyses was based on earlier studies performed by Hoffman et al. [45] and Józefiak et al. [46] to provide a necessary sample size for laboratory and statistical analysis, and to avoid unnecessary animal sacrificing (according to $4 \mathrm{R}$ policy).

The meat samples for analyses were taken from the large side muscle of fish body above the lateral line, the gills that was branchial arch with filaments, and the skeleton that was a spine with ribs. The meat, gills, and skeleton were crumbled and freeze-dried in Lyovac GT2 freeze-drier by Finn-Aqua (Finland) (parameters: temperature $-40{ }^{\circ} \mathrm{C}$, pressure 6 . $10^{-2}$ mbar, duration at least $48 \mathrm{~h}$ ).

\section{Minerals Analyses}

Metal concentrations were determined in freeze-dried samples after aqua regia digestion (ISO 11466:1995) using atomic absorption spectroscopy (AAS) with a SOLAR S4 spectrophotometer. Phosphorus content was analyzed with colorimetric method (ISO 13730:1996), by spectrophotometer Lambda 25, Perkin-Elmer (at wavelength $430 \mathrm{~nm}$ ). The concentrations of the metals were calculated from linear calibration plots obtained from measurements of the working standard solutions. Certified AAS Merck standard solutions were used for the calibration of the standard curves, and validation was conducted on Certified Reference Material Fish Muscle ERM®-BB422 and Certified Reference Material Aquatic Plant BCR $®-670$. All determinations were made in triplicate, and the data for samples of the meat were corrected to oven-dry $\left(105{ }^{\circ} \mathrm{C}\right)$ moisture content. Tissue concentrations of the metals were given in $\mathrm{mg} \mathrm{kg}^{-1}$ dry weight (mg kg-1 d.w.) for $\mathrm{Zn}$ and $\mathrm{Fe}$ and $\mathrm{g} \mathrm{kg}^{-1}$ dry weight $\left(\mathrm{g} \mathrm{kg}^{-1}\right.$ d.w.) for $\mathrm{Mg}, \mathrm{Ca}$, and P. Minerals analyses were conducted at UTP University of Science and Technology in Bydgoszcz (Poland).

\section{Statistical Analyses}

Statistical calculations were made using Statistica 13.0 software (StatSoft 13.0). The arithmetic mean (x) and standard deviation (SD) were calculated. Four fish per pond ( $n=16 ; 16$ fish for each treatment) were collected for minerals analyses. Significant differences between the groups were tested with one-way analysis of variance (ANOVA), and Tukey's test was used for multiple comparisons. The normality of the data was tested using the Shapiro-Wilk's test and the homogeneity of variance was verified by means of the Levene's test. The level of significance was determined at $P \leq 0.05$. Interrelationships between analyzed minerals in the individual tissues were determined based on the Pearson's correlation coefficients. 
Fig. 1 Effect of GOS

supplementation on $\mathrm{Ca}$

concentration ( $\mathrm{g} \mathrm{kg}^{-1}$ d.w.) in

tissues of common carp

(Cyprinus carpio L.)

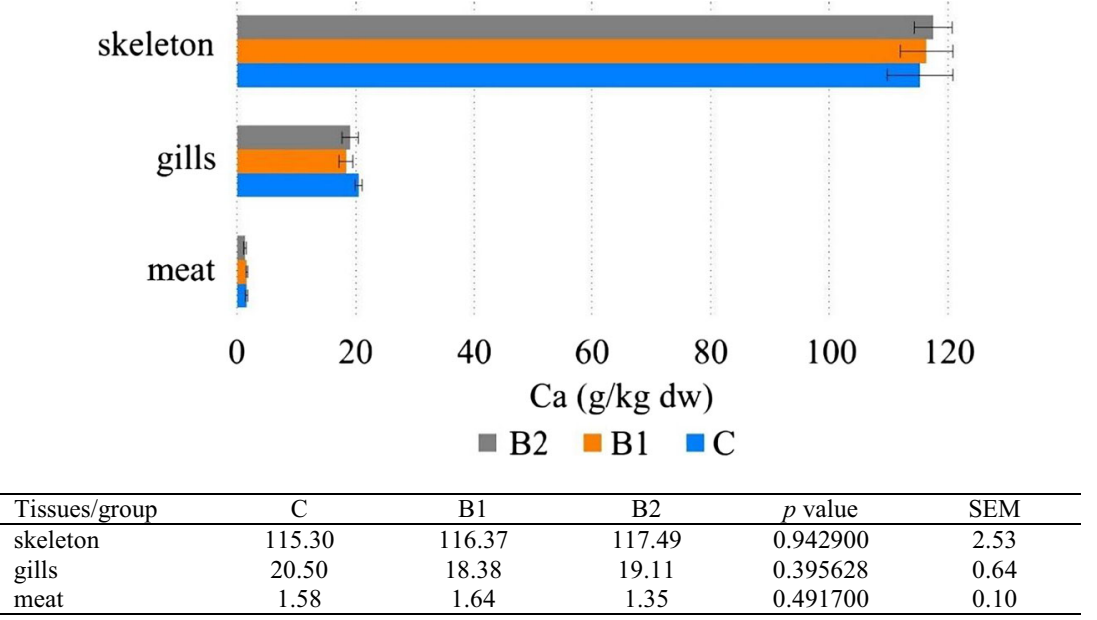

\section{Results}

\section{Concentrations of Minerals}

The results of the present study showed that $\mathrm{Ca}, \mathrm{Mg}$, and $\mathrm{P}$ concentration increased in tissues in the following order: meat $<$ gills $<$ skeleton. $\mathrm{Zn}$ and Fe concentration increased in the following order: meat $<$ skeleton $<$ gills (Figs. 1, 2, 3, 4, and 5). Analyses confirmed no statistically significant differences in $\mathrm{Ca}$ and $\mathrm{P}$ content between fish fed 1 and $2 \%$ GOS compared control treatment $(0 \%$ GOS) for each tissue (Figs. 1 and 2). $\mathrm{Ca} / \mathrm{P}$ ratio in the meat was 0.83 , in the gills 4.65 , and in the skeleton 2.13. The analyses confirmed that the value of this coefficient in the skeleton was significantly higher in B1 (2.25) and B2 (2.22) groups compared to the control (1.91). The highest level of $\mathrm{Mg}$ was detected in the skeleton of fish fed $1 \% \operatorname{GOS}\left(2.51 \mathrm{~g} \mathrm{~kg}^{-1} \mathrm{~d} . \mathrm{w}.\right)$, and was significantly higher compared control treatment ( $0 \%$ GOS) $\left(2.11 \mathrm{~g} \mathrm{~kg}^{-1}\right.$ d.w.), but this result was similar to the value determined for fish fed $1 \%$ $\operatorname{GOS}\left(2.34 \mathrm{~g} \mathrm{~kg}^{-1}\right)$. There were no statistically significant differences in $\mathrm{Mg}$ content between the experimental groups, both in the case of the meat and the gills (Fig. 3). The results of the present study showed that $\mathrm{Zn}$ contents in fish fed $1 \%$ GOS (31.21 $\mathrm{mg} \mathrm{kg}^{-1}$ d.w.) and 2\% GOS (35.41 $\mathrm{mg} \mathrm{kg}^{-1}$ d.w.) were significantly higher than control group $\left(24.59 \mathrm{mg} \mathrm{kg}^{-1}\right)$ (Fig. 4). Furthermore, it was found that enhancing feed GOS significantly affect the decrease in the $\mathrm{Zn}$ concentration in the skeleton. As our analyses of carp indicated, GOS addition caused statistically significant differences in Fe level between the experimental groups within all tissues (Fig. 5). Higher level of $\mathrm{Fe}$ was in the meat of fish fed $2 \%$ GOS (290.32 $\mathrm{mg} \mathrm{kg}^{-1}$ d.w.) in comparison with control group (94.86 mg kg-1 d.w.) and fish fed $1 \%$ GOS (111.33 $\mathrm{mg} \mathrm{kg}^{-1}$ d.w.). The concentration of this metal in the gills was in the range from $524.02 \mathrm{mg} \mathrm{kg}^{-1} \mathrm{~d} . \mathrm{w}$. (C group) to $586.52 \mathrm{mg} \mathrm{kg}^{-1} \mathrm{~d} . \mathrm{w}$. (B2 group), and these values differed significantly. Fe content in the skeleton differed significantly between the $\mathrm{C}$ group $\left(172.85 \mathrm{mg} \mathrm{kg}^{-1}\right.$ d.w.), B1 group (372.4 $\left.\mathrm{mg} \mathrm{kg}^{-1} \mathrm{~d} . \mathrm{w}.\right)$, and B2 group (447.89 $\mathrm{mg} \mathrm{kg}^{-1}$ d.w.).
Fig. 2 Effect of GOS supplementation on $\mathrm{P}$ concentration ( $\mathrm{g} \mathrm{kg}^{-1}$ d.w.) in tissues of common carp (Cyprinus carpio L.)

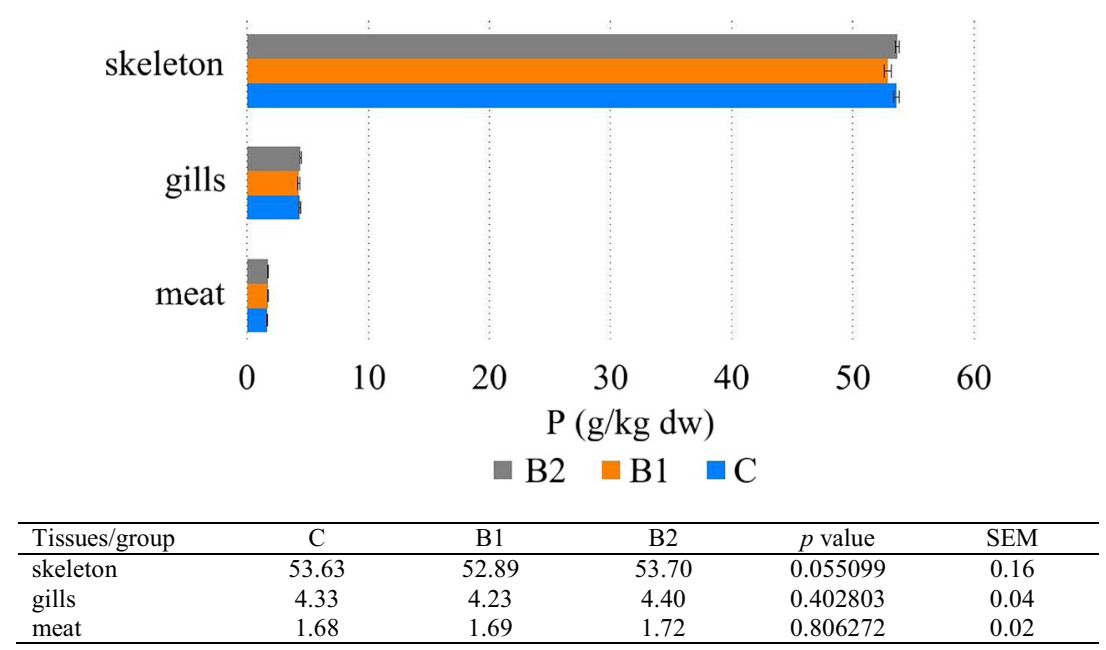


Fig. 3 Effect of GOS

supplementation on $\mathrm{Mg}$

concentration ( $\mathrm{g} \mathrm{kg}^{-1}$ d.w.) in

tissues of common carp

(Cyprinus carpio L.)

\section{Correlations Between Minerals}

Statistically significant correlation coefficients between $\mathrm{Fe}-$ $\mathrm{Ca}(r=0.997867 ; P<0.05)$ in the gills and $\mathrm{Fe}-\mathrm{Zn}(r=$ $0.997237 ; P<0.05)$ in the skeleton were observed in B2 group. Also, positive correlation coefficients between Mg-P in the meat $(r=0.999855 ; P<0.05)$ and in the skeleton $(r=$ 0.995238; $P<0.05$ ) were calculated in B2 group (Table 2 ).

\section{Discussion}

\section{Calcium Concentrations}

Calcium (Ca) is one of the most abundant cations in the fish body and affects the structure of the skeletal system and maintaining a proper acid-base balance. Absorption of $\mathrm{Ca}$ from the gastrointestinal tract is controlled by hormones such as parathyroid hormones (PTH), calcitonin, and 1,25dihydroxycholecalciferol [3]. As confirmed by research, muscle tissue is not the main site of $\mathrm{Ca}$ accumulation in fish as opposed to the fish scales, bones, and skin $[3,47]$. Our results on $\mathrm{Ca}$ accumulation in various tissues of common carp were in agreement with Brucka-Jastrzebska et al. [48] and Łuczyńska et al. [49]. Numerous studies have confirmed that prebiotics such as oligofructose, inulin, galactooligosaccharides, resistant starches, and lactulose effectively stimulate $\mathrm{Ca}$ absorption $[2$, 50]. It has been hypothesized that short-chain fatty acids (SCFA), acetate, propionate, and butyrate, and other organic acids (e.g., lactate) produced by prebiotics lower the $\mathrm{pH}$ of light in the large intestine, which is associated with an increased amount of soluble Ca, especially in the caecum [33]. Studies
Fig. 4 Effect of GOS

supplementation on $\mathrm{Zn}$ concentration (mg kg${ }^{-1}$ d.w.) in tissues of common carp (Cyprinus carpio L.)

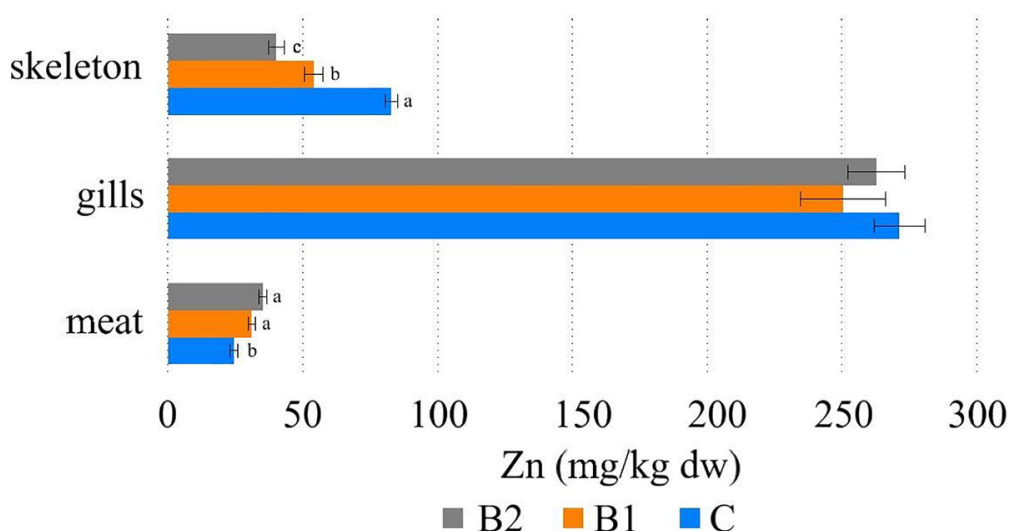

\begin{tabular}{lccccc}
\hline Tissues/group & $\mathrm{C}$ & $\mathrm{B} 1$ & $\mathrm{~B} 2$ & $p$ value & SEM \\
\hline skeleton & $82.63^{\mathrm{a}}$ & $54.16^{\mathrm{b}}$ & $40.23^{\mathrm{c}}$ & $<0.000001$ & 3.41 \\
gills & 271.31 & 250.41 & 262.97 & 0.489796 & 7.06 \\
meat & $24.59^{\mathrm{b}}$ & $31.21^{\mathrm{a}}$ & $35.41^{\mathrm{a}}$ & 0.000029 & 1.10 \\
\hline values in one line marked with different letters, differ statistically significantly at $\mathrm{P}<0.05 ; \mathrm{B} 1-1 \% \mathrm{Bi}^{2}$ tos ${ }^{\circledR}, \mathrm{B} 2-$ \\
$\begin{array}{l} \\
2 \% \mathrm{Bi}^{2} \text { tos }\end{array}$
\end{tabular}


have shown that the effect of the prebiotic on $\mathrm{Ca}$ absorption depends on the content of this mineral in the diet. Effect of GOS on $\mathrm{Ca}$ absorption was more effective when dietary $\mathrm{Ca}$ was higher than the recommended level [50, 51]. Our analyses showed no statistically significant differences in Ca content between fish fed 1 and $2 \%$ GOS compared control treatment ( $0 \%$ GOS) for each tissue. Therefore, further research is necessary to analyze the effect of different amounts of $\mathrm{Ca}$ in the diet on the effectiveness of the prebiotic activity on $\mathrm{Ca}$ absorption. Ortiz et al. [33] determined that content of $\mathrm{Ca}$ in the fillet of rainbow trout (Oncorhynchus mykiss) was not affected by prebiotic supplementation at inclusion level of $5 \mathrm{~g} \mathrm{~kg}^{-1}$ (FOS oligofructose BENEO P95; Beneo-Orafti Espanã SL, Barcelona, Spain). The lack of effect of the prebiotic on the absorption of $\mathrm{Ca}$ from the intestine may be due to the fact that the duration of the experiment was too short [50].

\section{Magnesium Concentration}

Magnesium (Mg) is a cofactor of almost 300 enzymes, and thus participates in the transformation of carbohydrates, proteins, lipids, and nucleic acids. This metal plays an important role in the transmission of information between muscles and nerves, and it inhibits the process of blood clotting, owing to which it prevents the formation of clots. $\mathrm{Mg}$, like $\mathrm{Ca}$ and phosphorus $(\mathrm{P})$, is necessary for bone mineralization and it accumulates in the greatest amounts in bones [52]. Our results regarding the level of $\mathrm{Mg}$ accumulation in various tissues were in line with Brucka-Jastrzębska et al. [48], Brucka-Jastrzębska and Protasowicki [53], Brucka-Jastrzębska and Kawczuga [54], and Łuczyńska et al. [49]. The results of the present study showed that the highest level of this mineral was detected in the skeleton of fish fed $1 \% \operatorname{GOS}\left(2.51 \mathrm{~g} \mathrm{~kg}^{-1}\right.$ d.w.), and was significantly higher compared control treatment ( $0 \%$ GOS)
(2.11 $\mathrm{g} \mathrm{kg}^{-1}$ d.w.). However, $2 \%$ GOS supplementation did not cause a significant increase in $\mathrm{Mg}$ content. As Guerreiro et al. [55] confirmed, it is possible that fish gut bacteria community and digestive enzymatic activity had to adapt to the dietary modification. The results of studies on the effect of prebiotics on animal health are often contradictory, as fermentability of prebiotics may be affected by several factors, such as the type and dose of the prebiotic for example. The study of Biggs et al. [56] demonstrated that excessively high prebiotic dose may have a negative impact on the gastrointestinal system and may delay the growth of animals. This could be related to the inability of gut bacteria to ferment the high amount of prebiotic provided in the diet. The opposite hypothesis is that GOS, as a prebiotic with a low degree of polymerization (PD), at a dose of 1 and $2 \%$, proved to be too weak in relation to the enzymes responsible for mineral metabolism. So, further research is needed to understand this mechanism. Our analyses confirmed no statistically significant differences in $\mathrm{Mg}$ content between treatment groups, both in the case of the meat and the gills. These results were in line with Ortiz et al. [33], who demonstrated that $\mathrm{Mg}$ content in the fillet of rainbow trout was not affected by prebiotic supplementation at inclusion level of $5 \mathrm{~g} \mathrm{~kg}^{-1}$. Factors that can reduce $\mathrm{Mg}$ absorption are fiber, phytates, $\mathrm{P}, \mathrm{Ca}$, or vitamin $\mathrm{D}$.

\section{Phosphorus Concentration}

Phosphorus (P) is a structural component of DNA, RNA, and phospholipids, involved in the photosynthesis and synthesis of organic compounds and responsible for the proper condition of teeth and bones. Fish can be a rich source of $\mathrm{P}$; the concentration of which, depending on the species, can reach up to $200 \mathrm{mg}$ per $100 \mathrm{~g}$ of meat. Phosphorus deficiency in the fish bodies can lead to excessive fat accumulation and poor
Fig. 5 Effect of GOS supplementation on $\mathrm{Fe}$ concentration ( $\mathrm{mg} \mathrm{kg}^{-1}$ d.w.) in tissues of common carp (Cyprinus carpio L.)

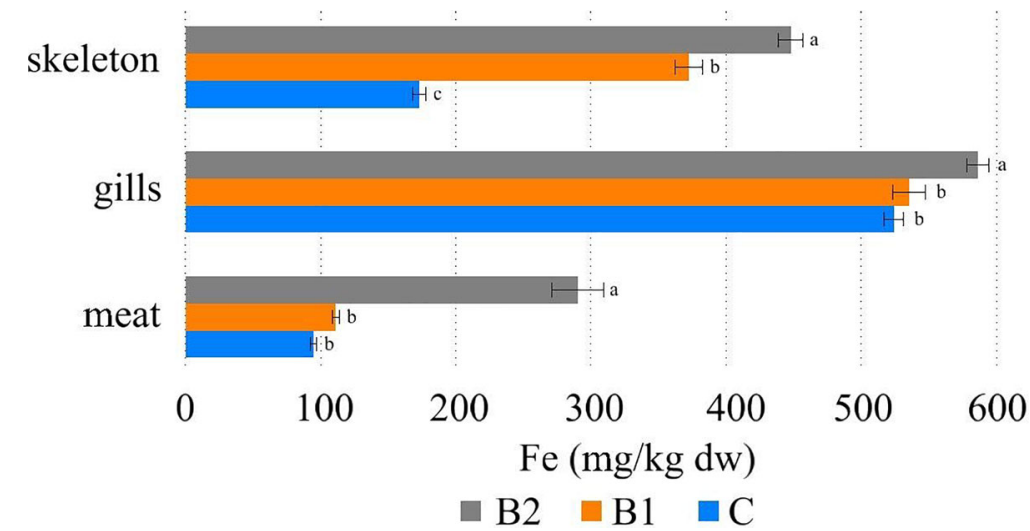

\begin{tabular}{lccccc}
\hline Tissue/group & $\mathrm{C}$ & $\mathrm{B} 1$ & $\mathrm{~B} 2$ & $p$ value & SEM \\
\hline skeleton & $172.85^{\mathrm{c}}$ & $372.40^{\mathrm{b}}$ & $447.89^{\mathrm{a}}$ & $<0.000001$ & 20.16 \\
gills & $524.02^{\mathrm{b}}$ & $535.66^{\mathrm{b}}$ & $586.52^{\mathrm{a}}$ & 0.000087 & 6.97 \\
meat & $94.86^{\mathrm{b}}$ & $111.33^{\mathrm{b}}$ & $290.32^{\mathrm{a}}$ & $<0.000001$ & 16.21 \\
\hline values in one line marked with different letters, differ statistically significantly at $\mathrm{P}<0.05 ; \mathrm{B} 1-1 \% \mathrm{Bi}^{2}$ tos ${ }^{\circledR}, \mathrm{B} 2-$ \\
$2 \% \mathrm{Bi}^{2}$ tos ${ }^{\circledR}$
\end{tabular}


Table 2 Effect of GOS supplementation on mineral correlation in tissues of common carp (Cyprinus carpio L.)

\begin{tabular}{|c|c|c|c|c|c|c|}
\hline \multirow[t]{2}{*}{ Tissues } & \multirow[t]{2}{*}{ Group } & \multirow[t]{2}{*}{ Minerals } & \multicolumn{4}{|c|}{ Correlation coefficients values (r) } \\
\hline & & & $\mathrm{Ca}$ & $\mathrm{P}$ & $\mathrm{Mg}$ & $\mathrm{Zn}$ \\
\hline \multirow[t]{12}{*}{ meat } & \multirow[t]{4}{*}{$\mathrm{C}$} & $\mathrm{P}$ & -0.848689 & & & \\
\hline & & $\mathrm{Mg}$ & 0.578071 & -0.059033 & & \\
\hline & & $\mathrm{Zn}$ & -0.522277 & -0.007777 & -0.997767 & \\
\hline & & $\mathrm{Fe}$ & 0.971402 & -0.949999 & 0.367790 & -0.304856 \\
\hline & \multirow[t]{4}{*}{ B1 } & $\mathrm{P}$ & 0.225148 & & & \\
\hline & & $\mathrm{Mg}$ & -0.039164 & 0.033006 & & \\
\hline & & $\mathrm{Zn}$ & 0.053271 & -0.218170 & -0.211447 & \\
\hline & & $\mathrm{Fe}$ & -0.539374 & 0.398583 & 0.390499 & 0.037665 \\
\hline & \multirow[t]{4}{*}{ B2 } & $\mathrm{P}$ & 0.324344 & & & \\
\hline & & $\mathrm{Mg}$ & 0.308206 & 0.999855 & & \\
\hline & & $\mathrm{Zn}$ & 0.526919 & 0.974871 & 0.970941 & \\
\hline & & $\mathrm{Fe}$ & -0.999823 & -0.342066 & -0.326032 & -0.542800 \\
\hline \multirow[t]{12}{*}{ gills } & \multirow[t]{4}{*}{$\mathrm{C}$} & $\mathrm{P}$ & 0.451383 & & & \\
\hline & & $\mathrm{Mg}$ & 0.102977 & 0.831992 & & \\
\hline & & $\mathrm{Zn}$ & -0.489005 & 0.075579 & -0.082084 & \\
\hline & & $\mathrm{Fe}$ & -0.342147 & 0.261913 & 0.422110 & 0.477769 \\
\hline & \multirow[t]{4}{*}{ B1 } & $\mathrm{P}$ & -0.084785 & & & \\
\hline & & $\mathrm{Mg}$ & 0.585839 & -0.857180 & & \\
\hline & & $\mathrm{Zn}$ & 0.759106 & -0.712984 & 0.972276 & \\
\hline & & $\mathrm{Fe}$ & 0.244280 & -0.986924 & 0.928984 & 0.816681 \\
\hline & \multirow[t]{4}{*}{ B2 } & $\mathrm{P}$ & 0.472731 & & & \\
\hline & & $\mathrm{Mg}$ & 0.826345 & -0.105625 & & \\
\hline & & $\mathrm{Zn}$ & 0.197073 & -0.770763 & 0.714970 & \\
\hline & & $\mathrm{Fe}$ & 0.997867 & 0.529242 & 0.787824 & 0.132660 \\
\hline \multirow[t]{12}{*}{ skeleton } & \multirow[t]{4}{*}{$\mathrm{C}$} & $\mathrm{P}$ & 0.630995 & & & \\
\hline & & $\mathrm{Mg}$ & 0.759933 & 0.275228 & & \\
\hline & & $\mathrm{Zn}$ & -0.216576 & -0.503354 & -0.547748 & \\
\hline & & $\mathrm{Fe}$ & 0.673275 & 0.240347 & 0.990319 & -0.631448 \\
\hline & \multirow[t]{4}{*}{ B1 } & $\mathrm{P}$ & 0.531779 & & & \\
\hline & & $\mathrm{Mg}$ & 0.767650 & 0.380443 & & \\
\hline & & $\mathrm{Zn}$ & -0.481985 & -0.396673 & -0.535817 & \\
\hline & & $\mathrm{Fe}$ & -0.788896 & -0.525375 & -0.398765 & -0.10209 \\
\hline & \multirow[t]{4}{*}{ B2 } & $\mathrm{P}$ & -0.826754 & & & \\
\hline & & $\mathrm{Mg}$ & -0.767979 & 0.995238 & & \\
\hline & & $\mathrm{Zn}$ & -0.455535 & 0.877420 & 0.920004 & \\
\hline & & $\mathrm{Fe}$ & -0.388142 & 0.839356 & 0.888347 & 0.997237 \\
\hline
\end{tabular}

Correlation coefficients marked in bold are statistically significant with $P<0.05 ; \mathrm{B} 1-1 \% \mathrm{Bi}^{2}$ tos ${ }^{\circledR}, \mathrm{B} 2-2 \% \mathrm{Bi}^{2}$ tos ${ }^{\circledR}$

skeletal mineralization and deformity [3]. It has also been shown that some phosphorus-containing compounds, such as phosphatidylinositol, play a very important role in preventing skeletal deformities [57]. Because the content of this mineral in the water is too low, and moreover, the efficiency of its absorption from feed is low, P should be supplemented with the feed [58]. Our studies have shown that as is the case of $\mathrm{Ca}, \mathrm{P}$ concentration increased in the following order: meat < gills < skeleton (Figs. 1 and 2), but there were no statistically significant differences in $\mathrm{P}$ content between fish fed 1 and $2 \%$ GOS compared control treatment $(0 \%$ GOS) for all tissues. However, noteworthy is the moderate increase in $\mathrm{P}$ of $2.33 \%$ (in the meat) recorded between $\mathrm{C}$ and B2 groups. Similarly, Ortiz et al. [33] demonstrated that content of $\mathrm{P}$ in the fillet of rainbow trout was not affected by FOS supplementation at inclusion level of $5 \mathrm{~g} \mathrm{~kg}^{-1}$. 
In vertebrates, calcium forms a complex with phosphorus as hydroxyapatite, which is responsible for the structure and the mechanical strength of bones [59], and therefore, the $\mathrm{Ca} / \mathrm{P}$ ratio is the most important indicator of good bone health because it prevents the reduction of bone mineral density [7]. The ratio of $\mathrm{Ca}$ to $\mathrm{P}$ in the whole body of several fish species ranges from 0.7 to 1.6 [7]. As numerous studies show, the value of this ratio should be 1:1 in consumed products, because the excess of calcium over phosphorus causes the formation of calcium triphosphate, which is not absorbed as this form of calcium triphosphate is not biologically available [59, 60]. Our analyses confirmed that $\mathrm{Ca} / \mathrm{P}$ ratio in the skeleton was affected by GOS supplementation and its value increased from 1.91 (C group) to 2.25 (B1) and 2.22 (B2). Our results were similar to those obtained by Nwanna and Swartz [12] for common carp fed phytase.

\section{Zinc Concentration}

Zinc $(\mathrm{Zn})$ plays an important role in the proper functioning of an organism, especially of the immune system; it is a component of many metalloenzymes, regulates metabolism of carbohydrates, proteins, nucleic acids, and participates in insulin synthesis and in bone mineralization $[60,61]$. The reduced rate of $\mathrm{Zn}$ uptake may be due to the presence of high amounts of calcium phosphate in feeds containing vegetable proteins, fiber, oxalates, phytates, and $\mathrm{Fe}$ [6]. Our results regarding $\mathrm{Zn}$ concentration in various tissues were in agreement with Bochenek et al. [62], Brucka-Jastrzębska et al. [48], Papagiannis et al. [63], and Jabeen et al. [64]. Prebiotic effect analyses revealed significantly higher amounts of $\mathrm{Zn}$ in the meat of fish from B1 and B2 groups in comparison with $\mathrm{C}$ group. Prebiotics like FOS and GOS promote growth of Bifidobacterium spp. that affect the synthesis of vitamin B6, which is responsible for better $\mathrm{Zn}$ absorption [65]. Since there is little data in the literature on this topic with regard to carp, further research is required. On the other hand, prebiotics affect the production of short-chain fatty acids, lowering the intestinal $\mathrm{pH}$, which may contribute to better absorption of $\mathrm{Zn}$. As confirmed by numerous studies, the gills play active and passive roles in exchanges between the body and its aquatic environment, and this tissue is the major storage site for $\mathrm{Zn}$ [3, 66, 67], which our research confirmed. However, our studies did not confirm a significantly positive effect of GOS supplementation on $\mathrm{Zn}$ concentration in the gills in B1 and $\mathrm{B} 2$ groups compared to $\mathrm{C}$ group, in contrast to the results obtained by Madreseh et al. [23] for rainbow trout lactulosefed.

\section{Iron Concentration}

Iron $(\mathrm{Fe})$ is a cofactor of many enzymes and a component of blood and muscle chromoproteins. This metal supports the proper functioning of the nervous and immune systems. In addition, $\mathrm{Fe}$ is responsible for the detoxification of harmful substances in the liver and prevents anemia, as it is responsible for the production of red blood cells. Fe content of the muscles of fish is an important criterion for their suitability for consumption. Factors that inhibit $\mathrm{Fe}$ absorption from intestine are fiber, phytates, polyphenols, and tannins [3]. Fe deficiency causes anemia, but its excess leads to the formation of reactive oxygen species, resulting in cell and tissue damage. Therefore, Fe homeostasis must be strictly controlled to maintain balance [68]. Carp analyses showed that the tendency of Fe accumulation in various tissues was similar to those determined by Brucka-Jastrzębska et al. [48], Brucka-Jastrzębska and Protasowicki [53], and Tekin Özan and Aktan [69]. As our analyses indicated, GOS addition caused significantly higher level of $\mathrm{Fe}$ in the meat of fish fed $2 \%$ GOS in comparison with $\mathrm{C}$ and $\mathrm{B} 1$ groups. These results were in contradiction with Ortiz et al. [33]. Research confirms the beneficial effect of prebiotics on $\mathrm{Fe}$ absorption because fermentation of these substances by the natural intestinal microflora may lower $\mathrm{pH}$ and promote the reduction of $\mathrm{Fe}(\mathrm{III})$ to $\mathrm{Fe}(\mathrm{II})$, whose solubility is better. Moreover, prebiotics can stimulate the proliferation of epithelial cells to increase the absorption surface and stimulate the expression of proteins responsible for the transport of minerals in epithelial cells [24]. In our previous study with the same fish [36], a significantly accelerated development of the intestine, an increase in the height and width of the villi and an increase in their surface due to the GOS were found. As confirmed by research, propionate which is produced by intestinal fermentation of oligosaccharides may stimulate promoting 6 -aminolevulinate synthesis ( $\gamma$-keto carboxylic acid and precursor to the synthesis of porphyrins). Also, oligosaccharides may lead to a change in iron-binding proteins, e.g., mucin and enhance $\mathrm{Fe}$ absorption in the small intestine [70]. Carp analyses indicated that the tissues which contained the largest amounts of Fe were the gills. Fe is taken up by the gills in the form of free ions and chelates of this element [34]. The hypothesis is that in a highly alkaline and oxidizing environment, Fe uptake through the gill epithelium is limited. Our research supports this hypothesis as we have observed a significantly higher concentration of $\mathrm{Fe}$ in the gills of fish fed 1 and $2 \%$ GOS, which may be due to the prebiotic lowering environmental $\mathrm{pH}$, but this mechanism requires further research.

\section{Minerals Interactions}

Antagonist relationships occur when minerals have a similar electronic configuration and ion radius and compete for binding sites. Synergistic relationships occur when one element strengthens the role of another. In turn, the complex interrelationships between $\mathrm{Fe}, \mathrm{Zn}$, and $\mathrm{Cu}$ are more complex [3]. Understanding the mechanism of the correlation of one 
element with another can be used as an indicator of their colocation in biological tissues [71]. Studies of Wepener et al. [72] have shown that $\mathrm{Cu}$ (and possibly $\mathrm{Fe}$ ) will have a greater tendency to accumulate in the gills than, for example, $\mathrm{Zn}$ or $\mathrm{Ca}$. Our analyses confirmed positive correlation between $\mathrm{Fe}$ and $\mathrm{Ca}$ in the gills in $\mathrm{B} 2$ group which indicated that $\mathrm{Ca}$ had affinity for divalent metal transporter (DMT1) [71, 73]. In can be concluded that $\mathrm{Fe}$ and $\mathrm{Ca}$ may share uptake pathway via the DMT-1. However, it should be taken into account that the interaction between $\mathrm{Fe}$ and $\mathrm{Ca}$ depends on the form of calcium. Carbonates and phosphates, unlike calcium citrate, inhibit Fe absorption. Despite the fact that GOS supplementation did not affect the level of $\mathrm{Ca}$ accumulation in carp tissues, our analysis showed that $2 \%$ GOS addition caused a statistically significant increase in Fe in the gills. This could have had a significant impact on the positive correlation between these minerals in $\mathrm{B} 2$ group.

Positive correlations between $\mathrm{Fe}$ and $\mathrm{Zn}$ and between $\mathrm{Mg}$ and $\mathrm{P}$ in the skeleton in $\mathrm{B} 2$ group were calculated, despite the fact that these elements are considered antagonists to each other. Despite the fact that our studies confirmed the greatest accumulation capacity of $\mathrm{Zn}$ in the gills and $\mathrm{Zn}$ content in the skeleton was lower, this metal confirmed a synergistic interaction with $\mathrm{Fe}$ in the group of fish treated with $2 \% \mathrm{GOS}$ supplementation. The interaction between $\mathrm{Fe}$ and $\mathrm{Zn}$ depends on the ratio of these metals to each other. The lack of published data on this topic requires further research on $\mathrm{Zn}$ metabolism, especially based on the analysis of vitamins and other minerals affecting $\mathrm{Zn}$ absorption.

Analyses confirmed positive correlation between $\mathrm{Mg}$ and $\mathrm{P}$ in the meat in $\mathrm{B} 2$ group. Although $\mathrm{P}$ and $\mathrm{Mg}$ are mainly involved in the bone mineralization process, their presence in the muscles is essential for the proper functioning of the organism. Both of these macroelements are responsible for conducting nerve impulses. Therefore, taking into account their proven antagonistic effect, the use of $2 \%$ GOS supplementation should be considered positive with regard to the correlation between these two elements. Due to the fact that there is no available published data about the effects of GOS on the relationship between minerals in carp tissues, this requires further analyses.

\section{Conclusions}

The results from the current study showed that dietary GOS supplementation had a positive effect on absorption of some minerals in common carp tissues. The feed with 1 and $2 \%$ of GOS supplementation significantly enhanced the concentration of $\mathrm{Zn}$ in the meat and skeleton. Fe concentration was significantly higher in the B2 group compared to B1 and C in the meat and gills. One percent and 2\% GOS supplementation significantly enhanced $\mathrm{Fe}$ content in the skeleton. $\mathrm{Mg}$ concentration was significantly higher in the skeleton of fish from $\mathrm{B} 1$ group compared to $\mathrm{C}$ group. A significant effect of 1 and $2 \%$ GOS supplementation on $\mathrm{Ca} / \mathrm{P}$ ratio in the skeleton was also confirmed. Supplementation of feed with $2 \%$ GOS significantly influenced the positive correlations between $\mathrm{Mg}$ and $\mathrm{P}$ in the meat and skeleton, $\mathrm{Fe}-\mathrm{Ca}$ correlation in gills, and $\mathrm{Fe}-\mathrm{Zn}$ correlation in the skeleton. Based on the analysis of the mineral profile in different tissues, we can conclude that the prebiotic could be a potential dietary additive for farmed common carp, due to the significant increase in $\mathrm{Fe}$ and $\mathrm{Zn}$, for example. The increased absorption of certain minerals may be caused due to the production of short-chain fatty acids, lowering the intestinal $\mathrm{pH}$ and regulating the factors responsible for the transport of divalent metals. Absorption of metals may be enhanced by vitamin synthesized by intestinal bacteria, which population is supported prebiotic. Another factor enhancing the minerals absorption may be an increase of the intestine development, an increase in the height and width of the villi, and an increase in their surface as a result of GOS supplementation, which was confirmed by our previous research on the same fish. Nevertheless, further research is needed in this topic to determine the detailed effects of GOS supplementation on minerals retention and on the interactions between minerals in different fish tissues.

Funding This work has been supported by the Polish National Agency for Academic Exchange under Grant No. PPI/APM/2019/1/00003. Research conducted by the statutory funding No. 506.511.04.00 of the Faculty of Veterinary Medicine and Animal Science Poznan University of Life Sciences, Poland; Division of Inland Fisheries and Aquaculture.

Data Availability The datasets generated during and/or analyzed during the current study are available from the corresponding author on reasonable request.

\section{Compliance with Ethical Standards}

Conflict of Interest The authors declare that they have no conflict of interest.

Ethical Approval All procedures performed in studies involving animals were in accordance with the ethical standards of the institution or practice at which the studies were conducted.

Open Access This article is licensed under a Creative Commons Attribution 4.0 International License, which permits use, sharing, adaptation, distribution and reproduction in any medium or format, as long as you give appropriate credit to the original author(s) and the source, provide a link to the Creative Commons licence, and indicate if changes were made. The images or other third party material in this article are included in the article's Creative Commons licence, unless indicated otherwise in a credit line to the material. If material is not included in the article's Creative Commons licence and your intended use is not permitted by statutory regulation or exceeds the permitted use, you will need to obtain permission directly from the copyright holder. To view a copy of this licence, visit http://creativecommons.org/licenses/by/4.0/. 


\section{References}

1. Prabhu PAJ, Schrama JW, Kaushik SJ (2016) Mineral requirements of fish: a systematic review. Rev Aquac 8(2):172-219. https://doi. org/10.1111/raq.12090

2. Krupa-Kozak U, Świątecka D, Bączek N, Brzóska MM (2016) Inulin and fructooligosaccharide affect: in vitro calcium uptake and absorption from calcium-enriched gluten-free bread. Food Funct 7:1950-1958. https://doi.org/10.1039/c6fo00140h

3. Lall SP (2002) The minerals. In: Halver J.E. and Hardy R.W, Fish Nutrition 259-308

4. Lochmann R, Phillips H, Xie L (2011) Effects of a dairy-yeast prebiotic and water hardness on the growth performance, mineral composition and gut microflora of fathead minnow (Pimephales promelas) in recirculating systems. Aquac 320(1-2):76-81. https://doi.org/10.1016/j.aquaculture.2011.08.004

5. Kamler E, Kamiński R, Wolnicki J, Sikorska J, Wałowski J (2012) Effects of diet and temperature on condition, proximate composition and three major macro elements, $\mathrm{Ca}, \mathrm{P}$ and $\mathrm{Mg}$, in barbel Barbus barbus juveniles. Rev Fish Biol Fish 18(4):767-777. https://doi.org/10.1007/s11160-012-9256-8

6. Sikorska J (2010) Dietary causes of body deformities in larval and juvenile fish in aquaculture. Part 1. Mineral substances. Komunikaty Rybackie 4(117): 1-4

7. Lall SP, Lewis-McCrea LM (2007) Role of nutrients in skeletal metabolism and pathology in fish - an overview. Aquac. 267:319

8. Hussein MS, Zaghlol A, Abd El Hakim NF, El Nawsany M, AboState HA (2016) Effect of different growth promoters on growth performance, feed utilization and body composition of common carp (Cyprinus carpio). J Fish Aquat Sci 11:370-377

9. Eurostat (2018) Agriculture, forestry and fishery statistics. Statistical books. https://ec.europa.eu/eurostat/documents/ 3217494/9455154/KS-FK-18-001-ENN.pdf/a9ddd7db-c40c48c9-8ed5-a8a90f4faa3f

10. FAO, Fisheries and Aquaculture, National Aquaculture Sector Overview - Poland 2020. http://www.fao.org/fishery/ countrysector/naso_poland/en

11. Roberts RJ (2002) Nutritional pathology. In: Halver J.E. and Hardy R.W. (eds), Fish Nutrition, Third Edition. Elsevier Science 453504

12. Nwanna LC, Schwarz FJ (2007) Effect of supplemental phytase on growth, phosphorus digestibility and bone mineralization of common carp (Cyprinus carpio L). Aquac Res 38(10):1037-1044. https://doi.org/10.1111/j.1365-2109.2007.01752.x

13. Kamiński R, Korwin-Kossakowski M, Kusznierz J, Myszkowski L, Stanny A, Wolnicki J (2005) Response of a juvenile cyprinid, lake minnow Eupallasella perenurus (Pallas), to different diets. Aquac Int 13:479-486. https://doi.org/10.1007/s10499-005-7899-3

14. Myszkowski L, Kamiński R, Quiros ML, Stanny A, Wolnicki J (2012) Dry diet-influenced growth, size variability, condition and body deformities in juvenile crucian carp Carassius carassius L. reared under controlled conditions. Arch Pol Fish 20:157-163. https://doi.org/10.2478/v10086-012-0019-x

15. Wolnicki J, Myszkowski L, Korwin-Kossakowski M, Kamiński R, Stanny A (2006) Effects of different diets on juvenile tench, Tinca tinca (L.) reared under controlled conditions. Aquac Int 14:89-98. https://doi.org/10.1007/s10499-005-9017-y

16. Akrami R, Razeghi Mansour M, Ghobadi S, Ahmadifar E, Shaker Khoshroudi M, Moghimi Haji MS (2013) Effect of prebiotic mannan oligosaccharide on hematological and blood serum biochemical parameters of cultured juvenile great sturgeon (Huso huso Linnaeus, 1754). J Appl Ichthyol 29:1214-1218. https://doi.org/ $10.1111 /$ jai.12245
17. Bharathi S, Cheryl A, Rajagopalasamy CBT, Uma A, Ahilan B, Aanand S (2019) Functional feed additives used in fish feeds. Int J Fish Aquat Stud 7(3):44-52

18. Cerezuela R, Meseguer J, Esteban A (2011) Current knowledge in symbiotic use for fish aquaculture: a review. J Aquac Res Dev S1: 008. https://doi.org/10.4172/2155-9546.S1-008

19. Khangwal I, Shukla P (2019) Potential prebiotics and their transmission mechanisms: recent approaches. JFDA 27:649-656

20. Mousavi E, Mohammadiazarm H, Mousavi SM, Ghatrami ER (2016) Effects of inulin, savory and onion powders in diet of juveniles carp Cyprinus carpio (Linnaeus 1758) on gut microflora, immune response and blood biochemical parameters. TrJFAS 16: 831-838

21. Ebrahimi G, Ouraji H, Khales MK, Sudagar M, Barari A, Zarei Dangesaraki M, Jani Khalili KH (2012) Effects of a prebiotics, Immunogen ${ }^{\circledR}$ on feed utilization, body composition, immunity and resistance of Aeromonas hydrophila infection in the common carp Cyprinus carpio (Linnaeus) fingerlings. J Anim Physiol Anim Nutr 96:591-599. https://doi.org/10.1111/j.1439-0396.2011. 01182.x

22. Ganguly S, Dora KC, Sarkar S, Chowdhury S (2012) Supplementation of prebiotics in fish feed: a review. Rev Fish Biol Fisheries 23:195-199. https://doi.org/10.1007/s11160-0129291-5

23. Madreseh S, Ghaisari HR, Hosseinzadeh S (2019) Effect of lyophilized, encapsulated Lactobacillus fermentum and lactulose feeding on growth performance, heavy metals, and trace element residues in rainbow trout (Oncorhynchus mykiss) tissues. Probiotics Antimicrob Proteins 11(4):1257-1263. https://doi.org/10.1007/ s12602-018-9487-7

24. Yeung CK, Glahn RP, Welch RM, Miller DD (2005) Prebiotics and iron bioavailability - is there a connection? Int J Food Sci 70(5):88 92

25. Yousefian M, Amiri MS (2009) A review of the use of probiotic in aquaculture for fish and shrimp. Afr J Biotechnol 8:7313-7318 http://www.academicjournals.org/AJB

26. Burr G, Hume M, Neill VH, Gatlin DM (2008) Effects of prebiotics on nutrient digestibility of soybean-meal-based diets by red drum (Sciaenops ocellatus). Aquacul Res 39:1680-1686. https://doi.org/ 10.1111/j.1365-2109.2008.02044.x

27. Dawood MAO, Koshio S, Esteban MÁ (2018) Beneficial roles of feed additives as immunostimulants in aquaculture: a review. Rev Aquac 10(4):950-974. https://doi.org/10.1111/raq.12209

28. Whisner CM, Castillo LF (2018) Prebiotics, bone and mineral metabolism. Calcif Tissue Int 102:443-479. https://doi.org/10.1007/ s00223-017-0339-3

29. McCabe L, Britton RA, Parameswaran N (2015) Prebiotic and probiotic regulation of bone health: role of the intestine and its microbiome. Curr Osteoporos Rep 13(6):363-371. https://doi.org/ 10.1007/s11914-015-0292-x

30. Gibson GR, Hutkins R, Sanders ME, Prescott SL, Reimer RA, Salminen SJ, Scott K, Stanton C, Swanson KS, Cani PD, Verbeke K, Reid G (2017) Expert consensus document: the International Scientific Association for Probiotics and Prebiotics (ISAPP) consensus statement on the definition and scope of prebiotics. Nat Rev Gastroenterol Hepatol 14:491-502. https://doi.org/ 10.1038/nrgastro.2017.75

31. Haq Z, Khan AA (2018) Prebiotics: the gut ecology modifiers. J Entomol Zool Stud 6(3):1816-1820

32. Macfarlane S, Macfarlane GT, Cummings J (2006) Review article: prebiotics in the gastrointestinal tract. Aliment Pharmacol Ther 24: 701-714. https://doi.org/10.1111/j.1365-2036.2006.03042.x

33. Ortiz LT, Velasco RS, Rodriguez M, Trevino J, Tejedor JL, Alzueta C (2012) Effects of inulin and fructooligosaccharides on growth performance, body chemical composition and intestinal microbiota 
of farmed rainbow trout (Oncorhynchus mykiss). Aquacul Nut 19(4):475-482. https://doi.org/10.1111/j.1365-2095.2012.00981.x

34. Niemiec M, Cupiał M, Klimas A, Szelag-Sikora A, Sikora J (2014) Accumulation of iron in selected elements of the pond ecosystem food chain. Proceedings of ECOpole 8(1):231-237. https://doi.org/ 10.2429/proc.2014.8(1)030

35. Tzortzis G, Goulas A, Gibson GR (2005) Synthesis of prebiotic galactooligosaccharides using whole cells of a novel strain, Bifidobacterium bifidum NCIMB 41171. Appl Microbiol Biotechnol 68(3):412-416. https://doi.org/10.1007/s00253-0051919-0

36. Ziółkowska E, Bogucka J, Dankowiakowska A, Rawski M, Mazurkiewicz J, Stanek M (2020) Effects of a transgalactooligosaccharide on biochemical blood parameters and intestine morphometric parameters of common carp (Cyprinus carpio L.). Animals 10(4):723. https://doi.org/10.3390/ani10040723

37. Leary S, Underwood W, Anthony R, Cartner S (2013) AVMA guidelines for the euthanasia of animals: 2013 edition; AVMA: Schaumburg, 67-73

38. Directive 2010/63/EU of the European Parliament and of the council of 22 September 2010 on the protection of animals used for scientific purposes

39. NRC (2011) Nutrient requirement of fish and shrimp. The National Academies Press, Washington, DC, Animal Nutrition Series

40. De Silva SS, Anderson TA (1995) Fish nutrition in aquaculture. Chapmann \& Hall, London, 319 pp

41. Takeuchi T, Satoh S, Kiron V (2002) Common carp, Cyprinus carpio. In: Webster CD, Lim C (eds) Nutrient requirements and feeding of finfish for aquaculture. CABI Publishing, New York, pp 245-261

42. Horváth L, Tamás G, Seagrave C (2002) Carp and pond fish culture, 2nd edn. Blackwell Science, Oxford, UK

43. Miyatake H (1997). Carp, Yoshoku, 34(5):108-111(in Japanese)

44. Topic Popovic N, Strunjak-Perovic I, Coz-Rakovac R, Barisic J, Jadan M, Persin Berakovic A, Sauerborn Klobucar R (2012) Tricaine methane-sulfonate (MS-222) application in fish anaesthesia. J Appl Ichthyol 28:553-564

45. Hoffmann L, Rawski M, Nogales-Merida S, Mazurkiewicz J (2020) Dietary inclusion of Tenebrio molitor meal in sea trout larvae rearing: effects on fish growth performance, survival, condition, and GIT and liver enzymatic activity. Ann Anim Sci 20(2): 579-598. https://doi.org/10.2478/aoas-2020-0002

46. Józefiak A, Nogales-Merida S, Rawski M, Kierończyk B, Mazurkiewicz J (2019) Effects of insect diets on the gastrointestinal tract health and growth performance of Siberian sturgeon (Acipenser baerii Brandt, 1869). BMC Vet Res 15:348. https:// doi.org/10.1186/s12917-019-2070-y

47. Liang JJ, Liu YJ, Yang ZN, Tian LX, Yang HJ, Liang GY (2012) Dietary calcium requirement and effects on growth and tissue calcium content of juvenile grass carp (Ctenopharyngodon idella). Aquac Nutr 18:544-550. https://doi.org/10.1111/j.1365-2095. 2011.00916.x

48. Brucka-Jastrzebska E, Kawczuga D, Rajkowska M, Protasowicki $\mathrm{M}$ (2009) Levels of microelements ( $\mathrm{Cu}, \mathrm{Zn}, \mathrm{Fe})$ and macroelements $(\mathrm{Mg}, \mathrm{Ca})$ in freshwater fish. J Elem 14(3):437-447

49. Łuczyńska J, Tońska E, Borejszo Z. (2011) Content of macro- and microelements, and fatty acids in muscles of salmon (Salmo salar L.), rainbow trout (Oncorhynchus mykiss Walb.), and carp (Cyprinus carpio L.). ŻYWNOŚĆ. Nauka. Technologia. Jakość 3(76):162-172

50. Cashman K (2003) Prebiotics and calcium bioavailability. Curr Issues Intest Microbiol 4:21-32

51. Bromage N, Randall C, Duston J, Thrush Mand Jones J (1993) Environmental control of reproduction in salmonids. In Recent Advances in Aquaculture IV pp 55-65
52. Perez-Conesa D, Lopez G, Abellan P, Ros G (2006) Bioavailability of calcium, magnesium and phosphorus in rats fed probiotic, prebiotic and synbiotic powder follow-up infant formulas and their effect on physiological and nutritional parameters. J Sci Food Agric 86:2327-2336

53. Brucka-Jastrzębska E, Protasowicki M (2006) Levels of selected metals in tissues and organs of 5-month-old carp (Cyprinus carpio L.). Acta Sci Pol Piscaria 5(2):3-16

54. Brucka-Jastrzębska E, Kawczuga D (2011) Levels of magnesium in tissues and organs of freshwater fish. J Elem 16(1):7-20

55. Guerreiro I, Serra CR, Pousão-Ferreira P, Oliva-Teles A, Enes P (2017) Prebiotcs effect on growth performance, hepatic intermediary metabolism, gut microbiota and digestive enzymes of white sea bream (Diplodus sargus). Aquacult Nutrit 24(1):153-163. https:// doi.org/10.1111/anu.12543

56. Biggs P, Parsons CM, Fahey GC (2007) The effects of several oligosaccharides on growth performance, nutrient digestibility, and cecal microbial populations in young chicks. Poult Sci 86(11):2327-2336. https://doi.org/10.3382/ps.2007-00427

57. Sikorska J, Wolnicki J, Kamiński R, Stolovich V (2012) Effect of different diets on body mineral content, growth, and survival of barbel, Barbus barbus (L.), larvae under controlled conditions. Arch Pol Fish 20:3-10. https://doi.org/10.2478/v10086-012-0001-

58. Cahu C, Zambonino Infante J, Takeuchi T (2001) Nutrients affecting quality in marine fish larval development. Eur Aquacult Soc Spec Publ 30:115-116

59. Ye C-X, Liu YJ, Tian L-X, Mai K-S, Du Z-Y, Yang H-J, Niu J (2006) Effect of dietary calcium and phosphorus on growth, feed efficiency, mineral content and body composition of juvenile grouper, Epinephelus coioides. Aquacult 255:263-271. https://doi.org/ 10.1016/j.aquaculture.2005.12.028

60. Chavez-Sanchez C, Martinez-Palacios CA, Martinez-Perez G, Ross LG (2000) Phosphorus and calcium requirements in the diet of the American cichlid Cichlasoma urophthalmus (Günther). Aquac Nutr 6:1-9. https://doi.org/10.1046/j.1365-2095.2000.00118.x

61. Kyu Song S, Beck BR, Kim D, Park J, Kim J, Kim HD, Ringø E (2014) Prebiotics as immunostimulants in aquaculture.: a review. Fish Shellfish Imm 40(1):40-48. https://doi.org/10.1016/j.fsi.2014. 06.016

62. Bochenek I, Protasowicki M, Brucka-Jastrzębska E (2008) Concentration of $\mathrm{Cd}, \mathrm{Pb}, \mathrm{Zn}$ and $\mathrm{Cu}$ in roach Rutilus rutilus (L.) from the lower reaches of the Oder River, and their correlation with concentrations of heavy metals in bottom sediments collected in the same area. Arch Pol Fish 16(1):21-36

63. Papagiannis I, Kagalou I, Leonardos J, Petridis D, Kalfakakou V (2004) Copper and zinc in four freshwater fish species from Lake Pamvotis (Greece). Environ Int 30:357-362. https://doi.org/10. 1016/j.envint.2003.08.002

64. Jabeen F, Chaudhry AS (2010) Monitoring trace metals in different tissues of Cyprinus carpio from the Indus River in Pakistan. Environ Monit Assess 170:645-656. https://doi.org/10.1007/ s10661-009-1263-4

65. Dylus E, Buda B, Górska-Frączek S, Brzozowska E, Gamian A (2013) Surface proteins of bacteria of the genus Bifidobacterium. Advances in Hygiene and Experimental Medicine 67:402-412. https://doi.org/10.5604/17322693.1049285

66. Dural M, Lugal Göksu MZ, Akif Özak A, Derici B (2006) Bioaccumulation of some heavy metals in different tissues of Dicentrarchus labrax L, 1758, Sparus aurata L, 1785, and Mugil cephalus L, 1758 from the Çamlik Lagoon of the eastern cost of Mediterranean (Turkey). Environ Monit Assess 118:65-74

67. Brooks RR, Rumsey D (1974) Heavy metals in some New Zealand commercial sea fishes mar. Freshw Res 8(1):155-166 
68. Zhao N, Enns CA (2012) Iron transport machinery of human cells: players and their interactions. Curr Top Membr 69:67-93. https:// doi.org/10.1016/B978-0-12-394390-3.00003-3

69. Tekin Özan S, Aktan N (2012) Relationship of heavy metals in water, sediment and tissues with total length, weight and seasons of Cyprinus carpio L,1758 from Işikli Lake (Turkey). J Zool 44: 1405-1416 https://www.researchgate.net/publication/286169833

70. Grizard D, Barthomeuf C (1999) Non-digestible oligosaccharides used as prebiotic agents: mode of production and beneficial effects on animal and human health. Reprod Nutr Dev 39:563-588

71. Saibua Y, Jamwal A, Feng R, Peak D, Niyogi S (2018) Distribution and speciation of zinc in the gills of rainbow trout (Oncorhynchus mykiss) during acute waterborne zinc exposure: interactions with cadmium or copper comparative biochemistry and physiology. Part C 206-207:23-31. https://doi.org/10.1016/j.cbpc.2018.02.004

72. Wepener V, van Vuren JHJ, Du Preez HH (2001) Uptake and distribution of a copper, iron and zinc mixture in gill, liver and plasma of a freshwater teleost, Tilapia sparrmanii. Water SA 27(1):99-108

73. Garrick MD, Singleton ST, Vargas F, Kuo HC, Zhao L, Knöpfel M, Davidson T, Costa M, Paradkar P, Roth JA, Garrick LM (2006) DMT1: which metals does it transport? Biol Res 39:79-85. https:// doi.org/10.4067/S0716-97602006000100009

Publisher's Note Springer Nature remains neutral with regard to jurisdictional claims in published maps and institutional affiliations. 